\title{
What is dietary metabolisable energy?
}

\author{
G.C. WAGHORN \\ Dexcel, Private Bag 3221, Hamilton, New Zealand \\ Garry.waghorn@dexcel.co.nz
}

\begin{abstract}
Metabolisable energy (ME) is frequently used as the sole indicator of forage quality by researchers, rural professionals and farmers, but it is hardly ever measured and is not always a good predictor of feeding value. Forage ME is usually calculated from chemical composition and digestibility, often by near infrared reflectance spectroscopy (NIRS). Although ME is superior to dry matter (DM) as a measure of feeding value and can indicate forage quality, it should not be used to predict animal production. The ME content of DM may imply a potential for production, but other components of the diet, especially protein, structural fibre and feed availability will provide more information than $\mathrm{ME}$ alone. Researchers, rural professionals and farmers should understand the basis for measuring ME, exercise discretion when using ME, and include fibre and protein concentrations in their criteria for feed appraisal.
\end{abstract}

Keywords: metabolisable energy, forage quality, feeding value

\section{Introduction}

Animal production is driven by intake and diet quality, defined as feeding value (Waghorn \& Clark 2004; Waghorn et al. 2007). Voluntary intake is determined by physiological demand, feed supply, ease of harvest and is influenced by feed composition and 'quality'. 'Quality' is a vague term but it can be described on the basis of chemical composition, by using the components crude protein $(\mathrm{CP})$, structural fibre (neutral detergent fibre; $\mathrm{NDF}$ ) and non-structural carbohydrates (sugars, starches and rapidly fermentable material). Essential components of quality also include six macro-and 10-12 microelements (Grace 1983, 1994) as well as vitamins and lipids. The complex and subjective components of feeding value may be responsible for the current use of ME, especially as animal production under New Zealand farming conditions is most often (but not always) limited by energy intake.

Dietary ME content is the energy in feed, minus energy in faeces, urine and methane that arise from digestion. Energy is measured by combustion (oxidation) in a bomb calorimeter. Metabolism in all living organisms is based on controlled and regulated oxidation of substrates and capture of energy in molecules able to do work, typically high energy phosphate bonds in ATP (adenosine triphosphate). In ruminants, the ME of a diet is calculated from the heat of combustion of feed eaten, minus the heat of combustion of faeces, urine and methane, derived from the feed eaten. It is the useful energy made available through the process of digestion.

The ME is used for animal maintenance (protein synthesis, ion transport - e.g. $\mathrm{Na}^{+}, \mathrm{K}^{+}$, heart work, breathing, eating, digestion etc.) and for production (Baldwin 1995). Production includes energy required to synthesise tissues (milk, meat, wool, conceptus etc.) as well as the energy in the product. Both maintenance and production require nutrients in addition to energy, and protein can be limiting in some situations, especially when poor quality or tropical $\left(\mathrm{C}_{4}\right)$ forages are fed to young, growing or lactating animals.

Metabolisable energy does provide a useful guide to the available energy (and economic value) of supplements and pasture, and ME values can be used to indicate production from defined intakes or to estimate intakes from production data. Forage ME values can be used to indicate "quality" within a feed type (e.g. over a growing season) but it is not a measure of nutrient content. This paper defines ME, its measurement and indicates some limitations for its use in nutrition.

\section{Measuring Metabolisable Energy}

Even though ME has become the estimate of choice for feed quality in New Zealand, it is very rarely measured. The procedure for measuring ME usually requires animals to be housed in metabolism stalls that enable accurate measurement of intake as well as faecal and urinary output of individuals. Measurements are made for 7-8 days following a period of adjustment to the test diet (minimum 14 days) and acclimatisation to the facilities. During the measurement period, methane production is measured, either by sulphur hexafluoride dilution and sampling adjacent to the nose (Woodward et al. 2002) or by measuring the change in methane concentrations in expired air if the animal is housed in a sealed chamber with measured airflow (respiration calorimeter) as described by Grainger et al. (2007).

The energy content of the feed offered and refused, urine and faeces are measured from sub-samples by combustion in a bomb calorimeter, and the energy intake and outputs calculated. The energy lost to methane is calculated from methane production and energy content $(55.4 \mathrm{~kJ} / \mathrm{g})$ and these data enable dietary ME to be calculated. 
The challenge faced by researchers to measure ME includes the cost of an animal trial (likely to be $\$ 10 \mathrm{k}$ \$20k for sheep, and \$40k - \$80k for cattle), requirements for faeces and urine collection from cattle and difficulty maintaining a relatively constant feed composition over the measurement period. Ryegrass pasture composition is notoriously variable, especially in spring/summer during flowering. Pasture needs to be long enough for mechanical harvest, and material fed may not be representative of the diet consumed under normal grazing management. A minimum of six animals is required to measure the ME of a diet, because of individual variation in digestion of feed.

Measurement of ME for silages or supplements poses greater problems if they cannot be fed as a sole diet, or are fed with pasture. For example, maize silage has insufficient protein, and palm kernel contains excess fat, for either to be fed alone, and the proportion of supplements fed with a base diet (e.g. pasture) affects their ME. The ME of two diets fed together will not necessarily be the sum of the proportions. The ME of supplements can be estimated by feeding several ratios of supplement (e.g. maize silage) with a base diet, for example: 0:100, 15:85, 30:70, 50:50, and regression analysis of the four dietary ME values will enable the value for maize silage to be calculated. However, the costs of measurement are prohibitive.

Metabolisable energy is usually measured when intakes are at, or just above, maintenance. Low intakes reduce feed refusals, and ensure a standard diet composition for individual animals, but ME is affected by intake, so values at maintenance are usually higher than values at higher intakes. A further problem with the determination of ME is that the errors associated with all aspects of the calculation become embedded in the calculated value, because it is based on differences between energy eaten and that lost to faeces, urine and methane

Metabolisable energy of forage is a superior measure to dry matter for estimating animal production potential, because it represents the energy available to the animal for maintenance and production. The ME value for forages is affected by composition, because composition affects digestion and digestibility (energy lost to faeces) and intake. Seasonal changes in forage composition (e.g. Burke \& Waghorn 2007), especially of grasses, affect ME values and a single measurement has limited value. However concentrations of CP and NDF in dietary DM can provide a good indication of feeding value.

\section{Predicting Metabolisable Energy}

Values for ME are usually based on predictions using NIRS or calculated from digestibility by assuming either $18 \%$ or $16 \%$ of digestible energy in roughages or concentrate, respectively, is lost to methane and urine during digestion (SCA 1990). NIRS is a low-cost measurement technique where dried and ground feed is scanned with a range of wavelengths (Corson et al. 1999) and the reflectance matched to a database of chemical composition and digestibility. The database is usually compiled from laboratory measurement of composition, typically NDF, CP, sugars, lipid and ash, in a range of samples, with digestibility measurements of diets with known composition fed to sheep or cattle. Equations may be used to calculate ME from digestibility values, dietary components, or both, and are proprietary information held by the analytical provider.

\section{Other Measures of Feeding Value}

Because ME is hardly ever actually measured, but sometimes calculated from components of a feed, it is logical to take a greater account of diet composition when predicting feeding value. This is especially true, given the balance of strengths and weaknesses of ME as a measure (Table 1). Principal feed components affecting feeding value are the concentrations of fibre, $\mathrm{CP}$ and, indirectly, the readily fermentable carbohydrate. Fibre concentration is usually defined as NDF and is a measure of plant cell wall content. The NDF maintains plant physical structure and is the principal determinant of

Table 1 What metabolisable energy can and cannot provide

$\mathrm{ME}$ is:

- A measure of energy available for work (maintenance and production)

- An indication of digestibility, because digestibility is the main influence on ME from forages

- An indicator of intake because a high ME implies high digestibility (and rapid passage), whereas low ME is associated with low (and slow) digestion

- An indicator of production, based on probable intakes and diet composition.

ME is not:

- A measure of diet composition, and does not indicate the adequacy of diet components for animal requirements

- Able to predict production, because of uncertainties in nutrient adequacy, feed availability, efficiency of nutrient utilisation, presence of pathogens or toxins in plants, or parasites in animals

- Able to be deduced for the whole diet by adding proportions of ME values for individual dietary constituents. 
intake in animals offered ad libitum feed (Mertens 1994). Fibre is composed of cellulose, hemicellulose and lignin, the latter being an indigestible 'glue' that binds the cellulose and hemicellulose together. Acid detergent fibre (ADF) is the component of NDF comprising cellulose and lignin. The difference between NDF and ADF concentrations represents the hemicellulose in fibre (Waghorn et al. 2007). Cell walls must be damaged by chewing to enable microbial digestion of cell contents (sugars, organic acids, soluble protein). Chewing is also necessary to break fibre into small pieces to increase rate of digestion of the cellulose and hemicellulose and to enable undigested residues to pass out of the rumen and finally to the faeces (Waghorn et al. 2007). Rate of passage and digestion determines the 'space' available in the rumen for more feed to be eaten.

Crude protein (\%) is usually measured as nitrogen (\%) $\mathrm{x} 6.25$, and about $60-80 \%$ of plant nitrogen is present as protein. Protein is important because deficits will constrain production, irrespective of $\mathrm{ME}$ availability, and excess CP is converted to urea for excretion. Synthesis of urea incurs an energetic cost to animals which increases the energy required for maintenance. Urea also represents a loss of available energy to the animal (by increasing urine energy).

Neutral detergent fibre and CP content affect digestibility and are the principal determinants of $\mathrm{ME}$ in forage diets. Concentrations of NDF in the DM of forages range from as low as $25 \%$ in clover and $35 \%$ in immature grass, through typical values of $43-53 \%$ in pasture (Burke $\&$ Waghorn 2007) to $65 \%$ or more in mature grass, straws and especially tropical $\left(\mathrm{C}_{4}\right)$ grasses. The values for $\mathrm{CP}$ are lower, with as little as $10 \%$ in senescent grass to $30 \%$ in fertilised pasture and legumes. Low concentrations of NDF are usually complemented by high concentrations of CP, so combined NDF + CP account for $60-70 \%$ of the DM.

The ash component of forages (8-10\% of DM) comprises mineral elements and their anions (sulphates, chlorides, phosphates) and has no energetic value, whereas lipid concentrations are low (3-6\% of DM) and have a medium digestibility. The NDF and CP account for about $65-75 \%$ of the potential ME and are good indicators of feeding value.

\section{Effect of Metabolisable Energy on Production}

There is an association between ME content of diets and voluntary intakes, with higher intakes from high $\mathrm{ME}$ diets, and the reverse. The impact of ME intake on milksolids (MS) yield was calculated for a $500 \mathrm{~kg}$ lactating cow (Table 2), assuming a single maintenance requirement of $57 \mathrm{MJ}$ ME/day (Nicol \& Brookes 2007) and that ME intake above maintenance was directed to MS production. The effect of ME intake is illustrated by comparing cows eating $15 \mathrm{~kg} \mathrm{DM} /$ day of pasture providing 10.5 vs. $12.5 \mathrm{MJ} \mathrm{ME} / \mathrm{kg}$ DM resulting in 1.30 vs. $1.69 \mathrm{~kg} \mathrm{MS} /$ day. Higher intakes result in larger differences in MS production because a lower proportion of feed ME is used to meet maintenance energy needs. If intakes of the respective diets were $17 \mathrm{~kg} \mathrm{DM} /$ day (Table 2), MS yields would be 1.57 and $2.01 \mathrm{~kg} /$ day.

The effect of ME intake on MS yields illustrates the dilution of maintenance in highly productive animals. For example, if maintenance required $57 \mathrm{MJ} \mathrm{ME} /$ day, this would be 27 and $36 \%$ of ME intakes of cows eating either $17 \mathrm{~kg} \mathrm{DM}$ at $12.5 \mathrm{MJ} \mathrm{ME} / \mathrm{kg} \mathrm{DM}$ or $15 \mathrm{~kg}$ of pasture containing 10.5 MJ ME/kg DM (Table 2).

The metabolisable energy requirement for maintenance used in these calculations (57 MJ/day) is lower than the $66 \mathrm{MJ} /$ day used by Holmes et al. (2002) because the

Table 2 Relationship between dietary metabolisable energy (ME) content (MJ/kg dry matter), intake of dry matter (DM) and ME/day and milksolids production for $500 \mathrm{~kg}$ Friesian dairy cows neither gaining nor losing weight. Data from Nicol and Brookes (2007).

\begin{tabular}{cccc}
\hline $\begin{array}{c}\text { Dietary ME } \\
(\mathrm{MJ} / \mathrm{kg} \mathrm{DM})\end{array}$ & $\begin{array}{c}\text { Daily Intakes } \\
\mathrm{kg} \mathrm{DM}\end{array}$ & MJ ME & Milksolids \\
10.5 & 13 & 136 & 1.03 \\
10.5 & 14 & 147 & 1.17 \\
10.5 & 15 & 157 & 1.30 \\
10.5 & 16 & 168 & 1.44 \\
10.5 & 17 & 178 & 1.57 \\
11.5 & 14 & 161 & 1.35 \\
11.5 & 15 & 172 & 1.49 \\
11.5 & 16 & 184 & 1.65 \\
11.5 & 17 & 195 & 1.79 \\
12.5 & 15 & 187 & 1.69 \\
12.5 & 16 & 200 & 1.86 \\
12.5 & 17 & 212 & 2.01 \\
12.5 & 18 & 225 & 2.18 \\
\hline
\end{tabular}

a Pasture contains $20 \%$ crude protein ${ }^{\mathrm{b}}$ Maintenance requires $57 \mathrm{MJ} \mathrm{ME} /$ day and $77 \mathrm{MJ} \mathrm{ME}$ for each $\mathrm{kg}$ of milksolids 
costs associated with support of the mammary gland and the digestion and grazing for milk production has been apportioned to the costs of milk synthesis. Metabolisable energy required to synthesise $1 \mathrm{~kg}$ of milksolids has risen from 68 (Holmes et al. 2002) to $77 \mathrm{MJ}$ ME (Nicol \& Brookes 2007).

\section{Gross Energy Content of Feeds}

The energy content of DM (gross energy, GE) is determined by the proportions of protein, fat, carbohydrate and ash. Heats of combustion $(\mathrm{MJ} / \mathrm{kg})$ are approximately 23.4 for protein, 39.7 for fat, 15.7 for glucose, 17.7 for starch, 17.5 for cellulose (McDonald et al. 1972) and ash does not release energy during combustion. The actual values for fat and protein also depend on their composition. Heat of combustion of crude protein (i.e. $\mathrm{N} \times 6.25$ ) will be lower than $23.4 \mathrm{MJ} /$ $\mathrm{kg}$ because $20-40 \%$ of crude protein is not true protein (Waghorn et al. 2007).

Although GE of feeds is best measured by calorimetry (combustion), approximate values can be calculated from chemical composition. For example, pasture comprising $24 \%$ CP, $5 \%$ fat, $62 \%$ carbohydrate and $9 \%$ ash in the DM would have a GE content of about $0.24 \times 23.4+$ $0.05 \times 39.7+0.62 \times 17.4=18.4 \mathrm{MJ} / \mathrm{kg}$ DM. Standard values for forages are $18.4 \mathrm{MJ} / \mathrm{kg}$ DM (SCA 1990) but high quality diets will have a higher GE than poor quality diets.

\section{Impact of Digestibility, Urine and Methane on Metabolisable Energy}

Digestibility has a major effect on ME because it determines energy loss to faeces. When cows were fed $14 \mathrm{~kg}$ pasture DM/day, with 9.5 - $12.5 \mathrm{MJ} \mathrm{ME} / \mathrm{kg} \mathrm{DM}$ (Table 3), the energy loss to faeces declined from 75 to $57 \mathrm{MJ}$ ( 31 to $21 \%$ of GE) as diet quality improved. The GE of poor quality pasture was $17.1 \mathrm{MJ}$ compared with 19.0 MJ/kg DM for good quality pasture.

Digestibility has the biggest impact on dietary ME relative to variations in energy loss to methane and urine. However, intake itself changes digestibility and consequently the energy loss to faeces and dietary ME availability. The general trend is for increasing intake to lower digestibility, and conversely, lower intake will increase digestibility because the diet is exposed to digestion for longer when intakes are low. Dietary ME is usually measured at about maintenance levels of intake, so the values will decrease as intake and production increases. The extent of the decrease in ME differs between diets and circumstances, with some systems suggesting a $1.8 \%$ decrease in ME for each multiple of maintenance intakes (SCA 1990). The extent of the decrease is not well defined and it is countered to some extent by lesser percentages of GE lost to methane from animals having high intakes. The value for ME is determined at a maintenance level of intake and is not a constant.

The calculations of energy losses to urine (Table 4) are based on measurements from cow diets containing 90$100 \%$ pasture (Bruinenberg et al. 2002; Kolver \& Aspin 2006), and show increased dietary nitrogen content was associated with increased energy loss (from 5 to $8 \%$ of $\mathrm{GE})$ to urine. There are very significant urinary nitrogen losses from animals fed pasture with excessive nitrogen concentrations (Table 4), and about $70-90 \%$ of urinary $\mathrm{N}$ is in urea (Church 1976; Bristow et al. 1992). Urea energy $(10.5 \mathrm{KJ} / \mathrm{g})$ accounts for only $30-45 \%$ of urinary energy. Using the example based on dairy cows fed 18 $\mathrm{kg}$ pasture DM with $28 \% \mathrm{CP}$ in the DM (Table 4), 26.5 MJ of energy was lost in urine, of which about $11 \mathrm{MJ} /$ day was urinary urea.

The energy loss to methane is $0.9-1.4 \mathrm{MJ} / \mathrm{kg} \mathrm{DM}$, (17-24 g/ $\mathrm{kg}$ DM intake) or 7-14\% of ME in sheep and cattle (Tables $3 \& 5$ ). Methane yield is lowest when high quality diets are fed, accounting for about $5 \%$ of GE, and increases to $8 \%$ of GE (or more) as quality declines (Robertson \& Waghorn 2003; Waghorn \& Woodward 2006).

In summary, the percentage of feed GE lost during digestion (Table 3 ) is highest from faeces (21-31\%), followed by methane (5-8\%) and urine (5-8\%).

\section{Maximum Metabolisable Energy from Forages}

Metabolisable energy is affected by both dietary GE concentration and losses of energy during digestion. Dietary GE is increased by fat and, to a lesser extent, protein content, and decreased by ash. Ruminant intakes decline if dietary fat exceeds about $7 \%$ of DM. This imposes an upper limit on dietary ME, but not necessarily dietary supplements. Forages rarely contain more than $7 \%$ fat or less than $8 \%$ ash, so a maximum GE is about $(0.07$ fat $\times 39.7)+(0.24$ protein $\times 23.4)+(0.61$ carbohydrate $\times 17.4)=19.0 \mathrm{MJ} / \mathrm{kg}$. If fed at maintenance, the maximum digestibility may reach $84 \%$, but methanogenesis will be elevated due to a long rumen residence time. At maintenance, no nitrogen will be retained and urinary energy will be about $7 \%$ of GE. Assuming 16\% of GE is lost to faeces, $7 \%$ to methane and $7 \%$ to urine, the ME will be $19.0-((0.16+0.07+$ $0.07) \times 19.0)=13.3 \mathrm{MJ} / \mathrm{kg}$ DM. This assumes all forage nitrogen was present as protein, but some will be nonprotein nitrogen, so the upper limit to pasture forage GE will be about $18.8 \mathrm{MJ} / \mathrm{kg} \mathrm{DM}$ and the upper limit for ME about $13.2 \mathrm{MJ} / \mathrm{kg} \mathrm{DM}$.

The maximum value for ME is unlikely to apply on farm because high quality diets are fed to productive animals, and as intakes increase, digestibility declines. The ME of forage crops will rarely exceed $12.5 \mathrm{MJ} / \mathrm{kg}$ 
Table 3 Effect of dietary metabolisable energy (ME) content on energy loss to methane, urine and digestion in a $500 \mathrm{~kg}$ lactating cow eating $14 \mathrm{~kg}$ dry matter (DM) per day.

\begin{tabular}{cccccccc}
\hline Dietary ME & $\begin{array}{c}\text { Gross energy } \\
\text { In diet }\end{array}$ & $\begin{array}{c}\text { Intake } \\
\text { MJ/kg DM }\end{array}$ & $\begin{array}{c}\text { MJ/kg DM } \\
\text { MJ/day }\end{array}$ & MJ/day & $\begin{array}{c}\text { Methane } \\
\text { MJ/day }\end{array}$ & $\begin{array}{c}\text { Energy loss (MJ/day) } \\
\text { Urine }^{\text {c }}\end{array}$ & $\begin{array}{c}\text { Energy } \\
\text { Faeces } \\
\text { digestion } \\
\%\end{array}$ \\
\hline 9.5 & 17.1 & 239 & 133 & 19 & 12 & 75 & 69 \\
10.5 & 17.8 & 249 & 147 & 17 & 15 & 70 & 72 \\
11.5 & 18.4 & 258 & 161 & 15 & 18 & 64 & 75 \\
12.5 & 19.0 & 266 & 175 & 13 & 21 & 57 & 79 \\
\hline
\end{tabular}

${ }^{a}$ Diets with a high ME content had higher crude protein, lipid and lower ash contents than poor quality diets. ${ }^{\mathrm{b}}$ Methane energy as a percentage of gross energy decreased from lowest to highest dietary ME from 8, 7, 6 and $5 \%$. ${ }^{\circ}$ Urinary energy as a percentage of gross energy increased from lowest to highest dietary ME from 5, 6, 7 and $8 \%$.

Table 4 Effect of dietary crude protein (CP) concentration on nitrogen $(\mathrm{N})$ partitioning to milka ${ }^{\mathrm{a}}$, faeces and urine, and urinary energy losses in a $500 \mathrm{~kg}$ Friesian cow fed pasture containing $11.5 \mathrm{MJ}$ metabolisable energy (ME).

\begin{tabular}{|c|c|c|c|c|c|c|c|}
\hline \multirow{2}{*}{$\begin{array}{l}\text { Intake } \\
\text { (kg/day) }\end{array}$} & \multirow{2}{*}{$\begin{array}{l}\text { Dietary } \\
\text { CP (\%) }\end{array}$} & \multirow{2}{*}{$\underset{\mathrm{N}}{\mathrm{digestion}(\%)}$} & \multirow{2}{*}{ Intake } & \multicolumn{2}{|c|}{ Nitrogen fluxes (g/day) } & \multirow[b]{2}{*}{ Urine } & \multirow{2}{*}{$\begin{array}{l}\text { Urine energy } \\
(\mathrm{MJ} / \text { day })^{\mathrm{c}}\end{array}$} \\
\hline & & & & Faeces & Milk $^{b}$ & & \\
\hline 14 & 18 & 68 & 403 & 129 & 92 & 182 & 12.9 \\
\hline 14 & 23 & 75 & 515 & 129 & 91 & 295 & 18.0 \\
\hline 14 & 28 & 82 & 627 & 113 & 88 & 426 & 20.6 \\
\hline 15 & 18 & 68 & 431 & 137 & 101 & 193 & 13.8 \\
\hline 15 & 23 & 75 & 552 & 138 & 101 & 313 & 19.3 \\
\hline 15 & 28 & 82 & 672 & 121 & 99 & 452 & 22.1 \\
\hline 16 & 18 & 68 & 460 & 147 & 112 & 201 & 14.7 \\
\hline 16 & 23 & 75 & 588 & 147 & 110 & 331 & 20.6 \\
\hline 16 & 28 & 82 & 716 & 129 & 110 & 477 & 23.5 \\
\hline 17 & 18 & 68 & 490 & 157 & 122 & 211 & 15.7 \\
\hline 17 & 23 & 75 & 625 & 156 & 120 & 349 & 21.9 \\
\hline 17 & 28 & 82 & 762 & 137 & 118 & 507 & 25.0 \\
\hline 18 & 18 & 16 & 518 & 166 & 132 & 220 & 16.6 \\
\hline 18 & 23 & 79 & 662 & 166 & 130 & 366 & 23.2 \\
\hline 18 & 28 & 82 & 806 & 145 & 129 & 532 & 26.5 \\
\hline
\end{tabular}

a Milk yields calculated from ME intakes, assuming maintenance requirements of 57,58 and $60 \mathrm{MJ} /$ day for diets containing 18,23 and $28 \%$ $\mathrm{CP}$ respectively, no change in body energy content and a requirement of $77 \mathrm{MJ} \mathrm{ME} / \mathrm{kg}$ milksolids synthesis. The variable maintenance energy assumes standard values (Nicol \& Brookes 2007) apply to diets containing 18\% CP and urinary N excretion from diets containing higher concentrations in the dry matter (DM) incur an additional metabolic cost (Waghorn et al. 2007). ${ }^{\mathrm{b}} 68 \mathrm{~g} \mathrm{~N} / \mathrm{kg}$ milksolids. ${ }^{\mathrm{c}}$ Assumes energy losses to urine are $5 \%, 7 \%$ and $8 \%$ of dietary gross energy when CP concentrations are $18 \%, 23 \%$ and $28 \%$ of the DM (Bruinenberg et al. 2002; Kolver \& Aspin 2006).

Table 5 Energy losses to methane by cows eating 14, 16 and $18 \mathrm{~kg}$ dry matter (DM)/day. Data assume a gross energy (GE) content of $17.1,17.8,18.4$ and $18.8 \mathrm{MJ} / \mathrm{kg} \mathrm{DM}$ and correspond to metabolisable energy contents of $9.5,10.5,11.5$ and $12.5 \mathrm{MJ} / \mathrm{kg} \mathrm{DM}$.

\begin{tabular}{rcccccc}
\hline $\begin{array}{l}\text { Dietary ME } \\
\text { MJ/kg DM }\end{array}$ & \% of GE & \multicolumn{3}{c}{$\begin{array}{c}\text { Methane losses to digestion } \\
\text { MJ/kg DM }\end{array}$} & \multicolumn{3}{c}{$\begin{array}{c}\text { Methane energy loss from cows (MJ/day) } \\
\text { at intakes of (kg DM/day) }\end{array}$} \\
\hline 9.5 & 5 & 0.96 & 17.3 & 13 & 16 & 18 \\
\hline 10.5 & 6 & 1.10 & 19.9 & 15.4 & 17.4 & 17.3 \\
11.5 & 7 & 1.24 & 22.2 & 17.4 & 19.8 & 19.8 \\
12.5 & 8 & 1.36 & 24.4 & 19.0 & 21.8 & 24.3 \\
\hline
\end{tabular}

DM, especially as concentrations of ash are usually higher, and lipid lower, than the example above, and digestibility will rarely exceed $80 \%$ in productive animals.

\section{Efficiency of Metabolisable Energy Utilisation}

Not all dietary or absorbed nutrients are used with equal efficiency. The nutrients that are absorbed by ruminants: volatile fatty acids (acetate, propionate, butyrate), amino acids and long chain fatty acids, are partitioned to meet the requirements for energy (oxidation) and production. There are variations between absorbed metabolites in the efficiency of utilisation. For example, more energy is captured by oxidising propionate than acetate or amino acids (Waghorn et al. 2007) so the proportions of 
nutrients and efficiencies of utilisation affect the use of ME for maintenance and, more especially, production (e.g. SCA 1990). Values for efficiency of ME use for maintenance range from 0.62 to 0.75 and values for growth range from 0.20 to 0.58 (SCA 1990; AFRC 1993). There are no simple equations able to predict the efficiency of energy use for production.

High energetic efficiencies are associated with diets that result in an active and efficient rumen microflora (efficient and rapid microbial growth), typically with a high proportion of propionate and adequate but not excessive nitrogen content. Total mixed rations, which contain $30-40 \%$ grain in the DM, meet these criteria. Legumes, especially those without excess nitrogen, can also result in a high proportion of propionate and very good production (Burke et al. 2002). In contrast, low efficiencies are associated with low propionate production and insufficient nutrient content, for example feeding straw, mature pasture or maize silage as a high proportion of a diet. Presence of toxins or parasites will lower the efficiency of nutrient utilisation.

The greater efficiency of energy utilisation from diets with a high ME value supports the use of ME to indicate feeding value, but users must be aware that ME can only provide an indication of production. There is little to be gained from comparisons between diets having similar estimated ME values, (e.g. 11.8 vs. $12.1 \mathrm{MJ} / \mathrm{kg} \mathrm{DM}$ ) because errors in sampling, prediction by NIRS, variations in intake, digestibility and composition of production will have an overriding effect on their feeding value.

\section{Conclusion}

The use of ME as an indication of feed quality has limitations that appear to be overlooked in many situations. Metabolisable energy is a robust indicator of energy potentially available for doing work, but it is rarely actually measured and usually predicted from feed digestibility or composition. Metabolisable energy does not measure nutrient content or nutritional adequacy. Increasing use of NIRS to estimate feed composition lessens the accuracy of ME predictions because a small sample of feed is analysed and NIRS is an estimate, rather than a measurement. There are no analytical measurements able to predict feeding value of diets, but intake and digestibility will be affected to a large degree by concentrations of fibre and crude protein in the DM. The NIRS system provides robust estimates of NDF and $\mathrm{CP}$ and these measurements should be used with ME to assess the feeding value of forages and the likely production of ruminants fed these forages.

\section{REFERENCES}

AFRC 1993. Energy and Protein Requirements of
Ruminants. An advisory manual prepared by the AFRC Technical Committee on Responses to Nutrients, CAB International, Wallingford, U.K. 175 pp.

Baldwin, R.L. 1995. Modelling ruminant digestion and metabolism. Chapman and Hall, London. 578 pp.

Bruinenberg, M.H.; van der Honing, Y.; Agnew, R.E.; Tan, T.; van Vuuren, A.M.; Valk, H. 2002. Energy metabolism of dairy cows fed on grass. Livestock Production Science 75: 117-128.

Bristow, A.W.; Whitehead, D.C.; Cockburn, J.E. 1992. Nitrogenous constituents in the urine of cattle, sheep and goats. Journal of the Science of Food and Agriculture 59: 387-394.

Burke, J.L.; Waghorn, G.C.; Brookes, I.M. 2002. An evaluation of sulla (Hedysarum coronarium) with pasture, white clover and lucerne for lambs. Proceedings of the New Zealand Society of Animal Production 62: 152-156.

Burke, J.L.; Waghorn, G.C. 2007. Feeding cows to make milk. pp. 115-124. In: Dairy 3. Ed. Brookes. I.M. Massey University, Palmerston North.

Church D.C. 1976. Digestive physiology and nutrition of ruminants. Volume 1. Digestive Physiology. O \& B Books, Corvalis, USA. 191 pp.

Corson, D.C.; Waghorn, G.C.; Ulyatt, M.J.; Lee, J. 1999. NIRS: forage analysis and livestock feeding. Proceedings of the New Zealand Grassland Association 61: 127132.

Grace, N.D. 1983. The mineral requirements of grazing ruminants. New Zealand Society of Animal Production. Occasional Publication No. 9. 150 pp.

Grace, N.D. 1994. Managing trace element deficiencies. New Zealand Pastoral Agriculture Research Institute, Hamilton, New Zealand. 70 pp.

Grainger, C.; Clarke, T.; McGinn, S.M.; Auldist, M.J.; Beauchemin, K.A.; Hannah, M.; Waghorn, G.C.; Clark, H.; Eckard, R.J. 2007. Methane emissions from dairy cows measured with the sulfur hexafluoride $\left(\mathrm{SF}_{6}\right)$ tracer and chamber techniques. Journal of Dairy Science 90: 2755-2766.

Holmes, C.W.; Brookes, I.M.; Garrick, D.J.; Mackenzie, D.D.S.; Parkinson, T.J.; Wilson G.F. 2002. Milk Production from Pasture, Palmerston North, Massey University. 601 pp.

Kolver E.S.; Aspin, P.W. 2006. Supplemental fumarate did not influence milksolids or methane production from dairy cows fed high quality pasture. Proceedings of the New Zealand Society of Animal Production 66: 409-415.

McDonald, P.; Edwards, R.A.; Greenhalgh, J.F.G. 1972. Animal Nutrition, Oliver \& Boyd, Edinburgh. $407 \mathrm{pp}$.

Mertens, D.R. 1994. Regulation of forage intake. pp 
450-493. In: Forage Quality, Evaluation and Utilization. Eds. Fahey, G.C.; Moser, L.E.; Mertens, D.R.; Collins, C. American Agronomy Society, Madison, WI.

Nicol, A.M.: Brookes, I.M. 2007. The metabolisable energy requirements of grazing livestock. pp 151172. In: Pastures and supplements for grazing animals. Eds. Rattray, P.V.; Brookes, I.M.: Nicol, A.M. New Zealand Society of Animal Production. Occasional publication No 14. Hamilton.

Robertson, L.J.; Waghorn, G.C. 2003. Dairy industry perspectives on methane emissions and production from cattle fed pasture or total mixed rations in New Zealand. Proceedings of the New Zealand Society of Animal Production 62: 213218.

SCA 1990. Australian Agricultural Council. Ruminants Subcommittee - Feeding standards for Australian livestock: Ruminants. CSIRO, Australia. 266 pp.

Waghorn, G.C.; Clark, D.A. 2004. Feeding value of pastures for ruminants. New Zealand Veterinary Journal 52: 320-331.

Waghorn, G.C.; Woodward, S.L. 2006. Ruminant contributions to global warming - a New Zealand perspective. pp. 233-260. In: Climate Change and Managed Ecosystems. Eds. Bhatti, J.S.; Lal, R.; Apps, M.L.; Price, M.A. Taylor \& Francis Boca Raton.

Waghorn, G.C.; Burke, J.L.; Kolver, E.S. 2007. Principles of feeding value. pp 35-59. In: Pasture and Supplements for Grazing Animals. Eds. Rattray, P.; Brookes, I.M.; Nicol, A. New Zealand Society of Animal Production. Occasional Publication No.14. Hamilton.

Woodward, S.L.; Waghorn, G.C.; Lassey, K.R.; Laboyrie, P.G. 2002. Does feeding sulla (Hedysarum coronarium) reduce methane emissions from dairy cows? Proceedings of the New Zealand Society of Animal Production 62: 227-230. 